\title{
NARROW-BAND UVB THERAPY AND TOPICAL CALCINEURIN INHIBITORS FOR THE TREATMENT OF PAEDIATRIC VITILIGO IN REAL CLINICAL PRACTICE
}

\author{
Ilona Hartmane ${ }^{1,2, \#}$ Ingmārs Mikažāns ${ }^{1,2}$, Iveta Ivdra ${ }^{1,2}$, Irēna Mirzajanova ${ }^{3,4}$, \\ Andra Dērveniece ${ }^{1,2}$, and Vanda Bondare-Ansberga ${ }^{1}$ \\ ${ }^{1}$ Clinical Centre of Skin and Sexually Transmitted Diseases, Rīga 1st Hospital, 5 Bruṇinieku Str., Rīga, LV-1001, LATVIA \\ 2 Department of Dermatology and Venerology, Rīga Stradiṇš University, 18 Baznīcas Str., Rīga, LV-1010, LATVIA \\ ${ }^{3}$ Department of Pharmacology, Rīga Stradiṇš University, 13 Pilsoṇu Str., Rīga, LV-1002, LATVIA \\ ${ }^{4}$ UAB Johnson \& Johnson Latvian branch, 101 Mūkusalas Str., Rīga, LV-1050, LATVIA \\ \# Corresponding author, ilona.hartmane@ rsu.Iv
}

Communicated by Ingrīda Rumba-Rozenfelde

\begin{abstract}
Vitiligo is an acquired chronic skin disease, characterised by progressing, usually symmetric, depigmented areas in human skin. Vitiligo affects $0.5 \%$ of the human population, however, optimal treatment combination real clinical practice has yet to be found. The aim of the study was to assess whether combined therapy with ultraviolet B (UVB) therapy and calcineurin inhibitors (CNI) provides superior response in vitiligo patients, compared with phototherapy or topical CNI monotherapy. We performed a retrospective cohort study of children treated for vitiligo from January 2016 to December 2019. Primary outcome measures include clinical efficacy defined by area of repigmentation - good clinical efficacy (re-pigmentation of $\geq 50 \%$ of lesion surface area), positive clinical efficacy and poor clinical efficacy (re-pigmentation of $<15 \%$ of lesion surface area). Secondary outcome measures included reduction of lesion size and tolerability of therapy. A total of 114 patients were recruited in the study, 46 allocated to the topical CNI therapy group, 36 to the narrow band (Nb-UVB), and 32 to the combined therapy group. All treatments statistically significantly decreased lesion surface area compared to the baseline (mean, SD). Local therapy reduced lesions from $8.5(5.7)$ to $5.3(4.2)$ by 37.3\% ( $\mathrm{p}<0.0001)$, phototherapy reduced lesions from 9.8 (5.4) to $5.7(3.92)$ by $42.3 \%(\mathrm{p}<0.0001)$, and combined therapy reduced lesions from 14.2 (4.8) to 6.58 (3.5) by $53.6 \%$ ( $\mathrm{p}<0.0001)$, with combined therapy showing superior numerical efficacy. Clinical efficacy for CNI monotherapy was $67.4 \%$, for phototherapy - $80.5 \%$, and for combined therapy $93.7 \%$. The safety profile of therapies was consistent with other studies. Our results support the use of combined therapy in vitiligo patients.
\end{abstract}

Key words: depigmentation, phototherapy, treatment, skin.

\section{INTRODUCTION}

Vitiligo is an acquired chronic skin disease, characterised by progressing, usually symmetric, depigmented areas in human skin. Vitiligo affects $0.5 \%$ of the human population. Literature data demonstrate that more than $50 \%$ of patients presenting with vitiligo are younger than 20 years (Taieb et al., 2007; Taieb et al., 2010; Alikhan et al., 2011; Senft et al., 2016). At this age vitiligo lesions influence the quality of life and are a reason for psychological and emotional stress, and social exclusion (Taieb et al., 2009; Whitton et al., 2010). A dominating histological sign is a decreased level or absence of melanin pigment in epidermal melanocytes provoked by autoimmune alterations. In the pathogenesis of vitiligo, genetic, immune, and biochemical factors play crucial roles. Nowadays, multiple pathogenic theories are proposed: neurological, autoimmune, self-destruction, genetic, and oxidative stress (Westerhof, 2007; Iannella et al., 2016). Currently, the proposed therapy methods for vitiligo are divided into non-invasive and surgical and are used in various combinations. The first group includes ultraviolet (UV) irradiation phototherapy, local 
immunomodulatory, immunosuppressive, photosensitising treatment methods, and skin bleaching agents. The invasive methods are autologous cell transplants, micropigmentation or, on the contrary, laser assisted depigmentation procedures. Complimentary therapies such as sunscreens, masking camouflage, psychotherapy can be applied (Gawkrodger et al., 2008; Whitton et al., 2010).

In treatment of vitiligo, multiple factors need to be considered, such as age, activity stage, concomitant diseases, especially of autoimmune origin, previously applied methods of treatment, as well as psychologic condition (Ongenae et al., 2006; Taieb et al., 2013). Prior to initiation of therapy, other autoimmune diseases are to be excluded, especially of the thyroid gland, such as autoimmune polyendocrine syndrome. One of the current methods of pathogenic treatment of vitiligo is UV phototherapy, particularly narrow band (wave length $311 \mathrm{~nm}$ ) ultraviolet B (UVB; TL-01 lamps) and topical treatment to decrease inflammation caused by immune factors (calcineurin inhibitors-CNI), which are indicated and proved to be safe, especially in paediatric practice. It is important to provide treatment with non-invasive, safe and effective methods of treatment that are well adapted to patients of different age groups. Literature data prove good clinical efficacy of topical CNI (tacrolimus $0.1 \%$ ointment and pimecrolimus $1 \%$ cream), as well as local corticosteroids, in treatment of patients presenting with vitiligo (Seirafi et al., 2007; Gawkrodger et al., 2008; Taieb et al., 2013; Sisti et al., 2016). CNI promotes hyperpigmentation by modulation of immune response and influencing melanocytes. Tacrolimus can supress the level of TNF- $\alpha$, a key inflammatory cytokine, elevated levels of which are found in vitiligo lesions and decrease production of melanocytes (Moretti et al., 2002; Grimes et al., 2004; Lan et al., 2005; Lee et al., 2013; Abyaneh et al., 2014). Tacrolimus can stimulate proliferation of melanocytes via stem cells present in vitiligo lesions in small quantities, their migration through metalloproteases (MMP-a) and synthesis of melanin (Moretti et al., 2002; Lan et al., 2005a; 2005b; Kang et al., 2009; Abyaneh et al., 2014).

Narrow band UVB phototherapy (Nb-UVB) is a pathogenically based method in treatment of vitiligo. UVB light induces activation, proliferation and migration of melanocytes. Proliferation is induced by melanocyte growth factor from keratinocytes (Wu et al., 2004; Hirobe et al., 2005). Migration of melanocytes is stimulated by phosphorylated focal adhesive molecules and matrix metalloproteinases MMP-2 (Lee et al., 2013; Abyaneh et al., 2014). Nb-UVB induces also tyrosinase to produce melanin (Kang et al., 2009). Nb-UVB mechanisms, which promote pigment production, are dual. Light induces inactive melanocyte stem cells in hair follicles and their activation, proliferation and migration in affected skin (Cui et al., 1991). Proliferation is induced by melanocyte growth factors like basic fibroblast growth factor (bFGF) and endothelin-1 from keratinocytes. There is a decrease of the bFGF level in vitiligo lesions. Migration of melanocytes is stimulated by phosphorylated focal adhesive kinases and expression of MMP-2 (Wu et al.,
2004). Nb-UVB alters the immunological response in the case of vitiligo, and particularly induces production of IL10 in epidermis, that in turn ensures differentiation of $\mathrm{T}$ regulatory cells. As a result, suppression of T-autoreactive cells occurs (Ponsonby et al., 2005).

$\mathrm{Nb}-\mathrm{UVB}$ modulates immunological response in the case of vitiligo, and particularly induces production of IL-10 in epidermis, that in turn ensures differentiation of $\mathrm{T}$ regulatory cells. As a result, suppression of T-autoreactive cells occurs (Lee et al., 2013). Nb-UVB can induce direct apoptosis of T lymphocytes, similar to the process in psoriatic lesions (Ponsonby et al., 2005; Lee et al., 2013).

This retrospective study aimed to assess whether combined therapy with UVB and CNI provides superior response in vitiligo patients, compared with phototherapy or topical monotherapy.

\section{MATERIALS AND METHODS}

This is a retrospective cohort study based on review of medical records from 114 patients diagnosed with vitiligo and treated at the Riga 1st Hospital. The study was approved by the ethics review board of Rìga Stradiņš University. The ICD-9 709.01 or ICD-10 L80 was used to identify patients treated for vitiligo from 1 January 2016 to 31 December 2019. Patients were grouped based on received therapy: group 1 - topical pimecrolimus cream two times a day, group 2 - Nb-UVB phototherapy (311 nm UVB) and moisturising skin care cream three times a week, and group 3 combined therapy, treated with topical pimecrolimus cream two times a day and Nb-UVB phototherapy in regimen $0.2-0.25 \mathrm{~J} / \mathrm{cm}^{2}$ three times a week, increasing by $5-20 \%$ in every next procedure until obtaining moderate erythema, after that the dosage was fixed. Inclusion criteria were (a) diagnosis of vitiligo by a dermatologist, (b) initiation of Nb-UVB (311 nm UVB) or topical calcineurin inhibitors (CNI), or combined Nb-UVB with CNI, (c) age of $<18$ years at the time of initiation of systemic therapy, and (d) duration of follow-up of at least three months. Exclusion criteria were (a) initiation of therapy prior to 1 January 2016, and (b) any missing data. Topical monotherapy was administered to the patients diagnosed with clinically significant comorbidities (metabolic syndrome, diabetes mellitus, and diseases of the thyroid gland). Nb-UVB was not applied to patients with Fitzpatrick skin phototype I, as well as in patients with history of extensive insolation if considered as a triggering factor for development of vitiligo. This method was not used also in cases when vitiligo lesions were localised in the skin of the periorbital area. Data were collected on demographics, clinical characteristics, systemic therapy and treatment response. The therapy method was assigned by the clinician based on clinical assessment at initial presentation and/or failure of previous therapies. The primary outcome measure was a comparison of treatment efficacy between three groups, defined as positive clinical efficacy (re-pigmentation of $\geq 15 \%$ of the lesion surface area), good clinical efficacy (re-pigmentation of $\geq 50 \%$ of the lesion surface area) and poor clinical effi- 
cacy (re-pigmentation of $<15 \%$ of the lesion surface area). Clinical efficacy was defined by the sum of patients achieving a positive and good clinical efficacy rate. Secondary outcome measures included reduction of lesion size and tolerability of therapy. Treatment response was recorded every month after initiation of therapy, and at the time of treatment termination. Termination of treatment was defined as discontinuing initial therapy. Lost to follow-up was defined as no follow-up scheduled appointment at time of data collection.

Variables were analysed using descriptive statistics. Qualitative variables were presented as counts and proportions and compared across groups via the Pearson's chi-square test for independence or Fisher's exact test as appropriate. Quantitative variables were presented using means and standard deviations (SD) and compared using two-tailed tests if normally distributed or as medians and interquartile ranges and compared using the Wilcoxon rank-sum test if not normally distributed. Secondary outcome measures were summarised by type of treatment. We compared the proportion of patients in each group reporting improvement based on skin lesion improvement, and reviewed side effects between groups. A statistical significance threshold of $p<0.05$ was used. Statistical analyses were performed with SPSS version 23.0 (IBM).

\section{RESULTS}

Demographic data are presented in Table 1, showing balanced distribution per treatment arm. All treatments statisti- cally significantly decreased lesion surface area compared to the baseline (mean, SD). Local therapy reduced lesions from $8.5(5.7)$ to $5.3(4.2)$ by $37.3 \%$ ( $p<0.0001)$, phototherapy reduced lesions from 9.8 (5.4) to 5.7 (3.92) by $42.3 \%(p<0.0001)$, and combined therapy reduced lesions from 14.2 (4.8) to $6.58(3.5)$ by $53.6 \%$ ( $p<0.0001)$, with combined therapy showing superior statistically significant efficacy. Thus, combined therapy provided the most significant reduction, shown in Figure 1. The impact of therapy on lesion re-pigmentation was assessed (Table 2). Clinical efficacy for CNI monotherapy was $67.4 \%$, for phototherapy $80.5 \%$, and for combined therapy $93.7 \%$. $75 \%$ of skin re-pigmentation was achieved in $10.8 \%$ cases of topical therapy, in $11.1 \%$ cases of CNI therapy, and in $12.5 \%$ of cases for combined therapy. Pairwise comparison showed superiority of phototherapy vs local therapy $(p=0.01)$, combined therapy vs local therapy $(p=0.002)$ and combined therapy vs phototherapy $(p=0.008)$. Duration of vitiligo and patient age during the therapy had no impact on response to therapy, measured as reduction of lesion size ( $p$ $>0.05)$. No difference in clinical outcomes was observed depending on patient gender $(p=0.353)$.

Comparing adverse drug reactions (ADR) between therapy groups, in the local therapy group no ADR were observed, in the phototherapy group one patient reported skin dryness that disappeared after application of a moisturiser, two patients reported short-term itching, and one patient reported a burning sensation that was managed by a moisturiser. In the combined therapy group, moderate erythema was detected in three patients, which quickly regressed after application

Table 1. Patient demographic data and lesion distribution between therapy groups

\begin{tabular}{|c|c|c|c|c|}
\hline Characteristic & $\begin{array}{l}\text { Local therapy group } \\
\qquad n=46\end{array}$ & $\begin{array}{l}\text { Phototherapy group } \\
n=36\end{array}$ & $\begin{array}{l}\text { Combined therapy group } \\
\qquad \mathrm{n}=32\end{array}$ & $p$-value \\
\hline \multicolumn{5}{|l|}{ Sex, n $(\%)$} \\
\hline Male & $17(37)$ & $14(38.9)$ & $13(40.6)$ & 0.948 \\
\hline Female & $29(63)$ & $22(61.1)$ & $19(59.4)$ & \\
\hline Age, years, mean \pm standard deviation & $\begin{array}{c}13.39 \pm 2.3 \\
\text { CI95\% }[12.7 ; 14.08]\end{array}$ & $\begin{array}{c}14.44 \pm 2.0 \\
\text { CI95\% }[13.76 ; 15.13]\end{array}$ & $\begin{array}{c}14.13 \pm 1.93 \text { CI95\% } \\
{[13.4 ; 14.8]}\end{array}$ & 0.075 \\
\hline Disease duration, years, mean \pm standard deviation, CI95\% & $\begin{array}{c}3.86 \pm 1.6 \\
\text { CI95\% }[3.4 ; 4.4]\end{array}$ & $\begin{array}{c}4.7 \pm 1.8 \\
\text { CI95\% }[4.0 ; 5.3]\end{array}$ & $\begin{array}{c}4.1 \pm 1.5 \\
\text { CI95\% }[3.5 ; 4.6]\end{array}$ & 0.507 \\
\hline \multicolumn{5}{|l|}{ Location of lesions, $\mathrm{n}(\%)$} \\
\hline Periorbital & $9(19.6)$ & $0(0)$ & $0(0)$ & \\
\hline Face & $19(41.3)$ & $10(27.8)$ & $11(34.4)$ & \\
\hline Body & $18(39.1)$ & $36(72.2)$ & $21(65.6)$ & \\
\hline Chest/trunk & $24(52.2)$ & 15 & $18(56.3)$ & \\
\hline \multicolumn{5}{|l|}{ Skin phototype } \\
\hline 1 & $4(8.7)$ & 0 & $0(0)$ & 0.043 \\
\hline 2 & $41(89.1)$ & 33 & $32(100)$ & \\
\hline 3 & $1(2.2)$ & 3 & $0(0)$ & \\
\hline Area of lesions, median (interquartile range) & $8.5(3.8-13.0)$ & $9.5(5.0-14.0)$ & $15.0(10.3-16.8)$ & $<0.001$ \\
\hline Duration of local therapy & $5.43(1.088)$ & $5.31(1.176)$ & - & \\
\hline Duration of phototherapy & - & $30.03(1.875)$ & $29.47(2.42)$ & \\
\hline \multicolumn{5}{|l|}{ Form of vitiligo, n (\%) } \\
\hline vulgaris & $34(73.9)$ & $23(63.9)$ & $32(100)$ & 0.001 \\
\hline segmentary & $12(26.1)$ & $13(36.1)$ & $0(0)$ & \\
\hline
\end{tabular}




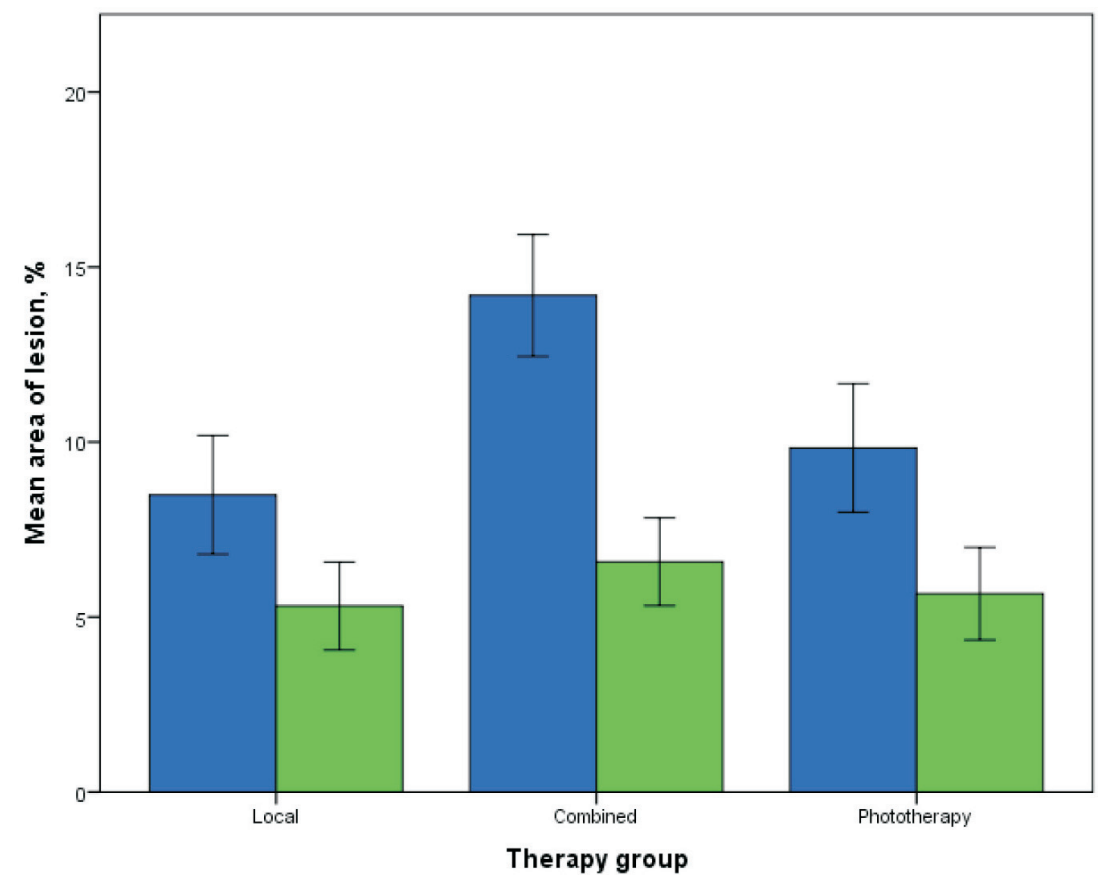

Area of lesions before therapy, $\%$

Area of lesions after therapy, $\%$
Fig. 1. Lesion area before and after per therapy group, $p<0.05$.

Table 2. Evaluation of therapy efficacy

\begin{tabular}{l|c|c}
\hline \multicolumn{1}{c|}{ Results of treatment } & $\begin{array}{c}\text { Local therapy group, } \\
\mathrm{n}=46(\%)\end{array}$ & $\begin{array}{c}\text { Phototherapy group, } \\
\mathrm{n}=36(\%)\end{array}$ \\
\hline Poor efficacy & $15(32.6)$ & $7(19.4)$ \\
Positive clinical efficacy & $8(17.4)$ & $17(47.2)$ \\
Good clinical efficacy & $23(50.0)$ & $12(33.3)$ \\
Percentage of reduction of the skin lesion area $\mathrm{p}<0.05$ & $37.3 \%$ & $42.3 \%$
\end{tabular}

of topical dexpanthenol foam; one patient reported itchy sensations that disappeared without additional intervention; in one patient burning sensations were noticed and well managed by a moisturiser. Reported ADR were non-serious and all patients completed the assigned therapy course.

\section{DISCUSSION}

The data obtained and literature data demonstrate that $\mathrm{Nb}$ UVB phototherapy is clinically efficacious and a safe method with no clinically significant side effects in treatment of vitiligo patients in children and adolescent populations.

It is known that vitiligo treatment is more difficult for patients with lighter skin. Unlike other countries, individuals with skin phototype 2 are dominating in Latvia, there are only a small number of individuals with skin phototypes 3 and 1 , and very few individuals with skin phototypes 4,5 , and 6. Therefore, in our study, most patients had skin phototype 2, and only four patients had the first skin phototype and four patients had the third skin phototype. Lighter skin is associated with a higher risk of UVB therapy side effects.
By including individuals with mostly light-coloured skin in our study, it was very important to find out whether therapy for vitiligo would be less effective and whether there would be more side effects compared with the description from other authors. The effectiveness and safety of combined therapy from UVB and locally applied calcineurin inhibitor could thus be assessed.

The results of the current work support the trend of better efficacy of combined therapy over monotherapy in patients with large areas of lesions. For the first time, efficacy of $311 \mathrm{~nm} \mathrm{Nb-UVB}$ phototherapy in vitiligo in paediatric population was described in 2000. According to published data, 51 patients in the age group from 4 till 16 presenting with a generalised form of vitiligo were treated with $311 \mathrm{~nm}$ $\mathrm{Nb}-\mathrm{UVB}$ phototherapy in duration from 6 till 12 months. The area of re-pigmentation of vitiligo lesions more than $75 \%$ was reached in $53 \%$ of cases (Njoo et al., 2000). Similar results were described by other authors, where re-pigmentation of more than $75 \%$ of vitiligo lesion surface was reached accordingly in 50 and $75 \%$ paediatric population patients treated with $311 \mathrm{~nm} \mathrm{Nb-UVB}$ phototherapy (Brazzeli et al., 2005; Kanwa et al., 2006). Chen et al. (2005) found that $311 \mathrm{~nm} \mathrm{Nb-UVB}$ phototherapy was efficacious in more than $70 \%$ of children and adolescent 
vitiligo patients with duration of treatment for 12 months. CNI induces re-pigmentation, modulating immune response by influencing melanocytes (Moretti et al., 2002; Grimes et al., 2004; Lan et al., 2005; Lee et al., 2013). Interestingly, tacrolimus decrease level of TNF- $\alpha$ found in vitiligo lesions in considerable amounts upregulate production of melanin (Abyaneh et al., 2014). Publications indicate that in vitiligo the combined treatment of CNI and $311 \mathrm{~nm} \mathrm{Nb-UVB}$ phototherapy shows better clinical efficacy. Results of an investigation performed by Lotti et al. (2008) showed that clinical efficacy was reached in $54.6 \%$ of cases by applying pimecrolimus for six months, and in $76.5 \%$ of cases by administering the combined method.

Similar results were obtained in this study. Combined therapy showed significantly higher therapeutic efficacy compared to UVB phototherapy and topical calcineurin inhibitor therapy by evaluation of the percentage reduction of the skin lesion area.

Clinical efficacy for CNI monotherapy was $67.4 \%$, for phototherapy - 80.5\%, and for combined therapy $93.7 \%$. Both local therapy and Nb-UVB therapy had a relatively high proportion of poor responders to therapy, compared to the combined therapy group - 32.4\%, $19.4 \%$, and $6.3 \%$, respectively. $75 \%$ of skin repigmentation was achieved in a limited proportion of patients: $10.8 \%$ cases for topical CNI therapy, $11.1 \%$ for phototherapy, and $12.5 \%$ for combined therapy. This finding highlights the need in vitiligo patients for more efficacious treatment options. A previous comparative study demonstrated a significant difference in $\geq 50 \%$ re-pigmentation of facial lesions in vitiligo patients treated with Nb-UVB phototherapy and pimecrolimus, in contrast to $\mathrm{Nb}-\mathrm{UVB}$ phototherapy and a placebo: $64.3 \%$ and $25.1 \%$ $(p<0.05)$, respectively. Statistically significant and similar results were shown in a study of $\mathrm{Nb}-\mathrm{UVB}$ and tacrolimus $0.1 \%$ ointment (Esfandiarpour et al., 2009; Nordal et al., 2011). The phototherapy and combined therapy related side effects were generally mild and disappeared with moisturisers, which outlines the favourable and manageable safety profile desired in paediatric populations. With combined therapy, no increase in ADR was observed. Side effects in other studies showed comparable results to those detected in our investigation - minor erythema, itch and burning sensations (Njoo et al., 2000; Brazzeli et al., 2005; Tran et al., 2005; Kanwa et al., 2006). To conclude, combined topical $\mathrm{CNI}$ therapy with $\mathrm{Nb}-\mathrm{UVB}$ course provides high response rates, acceptable re-pigmentation results and a favourable safety profile in real clinical practice.

\section{CONCLUSIONS}

The data from the study demonstrate that the combined treatment method is statistically reliable and therefore recommended in clinical practice of dermatology.

To raise the therapeutic efficacy and to decrease the risk of development of side effects, the combined method is recom- mended in the treatment of vitiligo using Nb-UVB phototherapy and topical calcineurin inhibitor.

The combined method of treatment provides superior results in comparison with monotherapy of topical calcineurin inhibitor or Nb-UVB phototherapy. Results of our comparative study prove the safe use of CNI $1 \%$ pimecrolimus cream in treatment of vitiligo patients. Monotherapy can be applied in cases when there is intolerance or contraindications for $\mathrm{Nb}-\mathrm{UVB}$ phototherapy.

\section{REFERENCES}

Abyaneh, M. Y., Griffith, R. D., Falto-Aizpurua, L., Nouri, K. (2014). Narrowband ultraviolet B phototherapy in combination with other therapies for vitiligo: Mechanisms and efficacies. J. Eur. Acad. Dermatol. Venereol., 28, 1610-1622.

Alikhan, A., Felste,, L. M., Daly, M., Petronic-Rosic, V. (2011). Vitiligo: A comprehensive overview. Part I. Introduction, epidemiology, quality of life, diagnosis, differential diagnosis, associations, histpathology, etiology, and work-up. J. Amer. Acad. Dermatol., 65, 473-491.

Brazzeli, V., Prestinari, F. (2005). Useful treatment of vitiligo in 10 children with UV-B-narrow-band (311 nm). Pediatr. Dermatol., 22, 257-261.

Chen, G. Y., Hsu, M. M., Tai, H. K. (2005). Narrow-band UVB treatment of vitiligo in Chinese. J. Dermatol., 10, 793-800.

Cui, J., Shen, L. Y., Wang, G. C. (1991). Role of hair follicles in the repigmentation of vitiligo. J. Invest. Dermatol., 97, 410-416.

Esfandiarpour, I., Ekhlasi, A., Farajzadeh, S., Shamsadini, S. (2009). The efficacy of pimecrolimus $1 \%$ cream plus narrow-band ultraviolet $\mathrm{B}$ in the treatment of vitiligo: A double- blind, placebo-controlled clinical trial. $J$. Dermatol. Treat., 20, 14-18.

Fai, D., Cassano, N., Vena, G. A. (2007). Narrow-band UVB phototherapy combined with tacrolimus ointment in vitiligo: A review of 110 patients. $J$. Eur. Acad. Dermatol. Venereol., 21, 916-920.

Gawkrodger, D. J., Ormerod, A. D., Shaw, L., Mauri-Sole, I., Whitton, M. E., Watts, M. J. (2008). Guideline for the diagnosis and management of vitiligo. Brit. J. Dermatol., 159, 1051-1076.

Grimes, P. E., Morris, R., Avaniss-Aghajani, E., Soriano, T., Meraz, M., Metzger, A. (2004). Topical tacrolimus therapy for vitiligo: Therapeutic responses and skin messenger RNA expression of proinflammatory cytokines. J. Amer. Acad. Dermatol., 51, 52-61.

Hirobe, T. (2005). Role of keratinocyte-derived factors involved in regulating the proliferation and differentiation of mammalian epidermal melanocytes. Pigment Cell Res., 18, 2-12.

Iannella, G., Greco, A., Didon, D., Didona, B., Granata, G., Manno, A., Pasquariello, B., Magliulo, G. (2016). Vitiligo: Pathogenesis, clinical variants and treatment approaches. Autoimmun. Rev., 15, 335-343.

Kang, H. Y., Choi, Y. M. (2009). FK 506 increases pigmentation and migration of human melanocytes. Brit. J. Dermatol., 155, 1037-1040.

Kanwar, A. J., Dogra, S. (2006). Narrow-band UVB for the treatment of generalized vitiligo in children. Clin. Exp. Dermatol., 45, 63-65.

Klahan, S., Asawanonda, P. (2009). Topical tacrolimus may enhance repigmentation with targeted narrowband ultraviolet B to treat vitiligo: A randomized, controlled study. Clin. Exp. Dermatol., 34, 1029-1030.

Lan, C. C., Che, G. S., Chiou, M. H., Wu, C. S., Chang, C. H., Yu, H. S. (2005a). FK506 promotes melanocyte and melanoblast growth and creates a favourable milieu for cell migration via keratinocytes: Possible mechanisms of how tacrolimus ointment induces repigmentation in patients with vitiligo. Brit. J. Dermatol., 153 (3), 498-505.

Lan, C. C., Chen, G. S., Chiou, M. H. (2005b). FK 506 promotes melanocyte and melanoblast growth and creates a favourable milieu for cell migration via keratinocytes. Brit. J. Dermatol., 153, 496-505. 
Lee, K. Y., Jeon, S. Y., Hong, J. W., Choi, K. W., Lee, C. Y., Choi, S. J., Kim, J. H., Song, K. H., Kim, K. H. (2013). Endothelin-1 enhances the proliferation of normal human melanocytes in a paradoxical manner from the TNF- $\alpha$-inhibited condition, but tacrolimus promotes exclusively the cellular migration without proliferation: A proposed action mechanism for combination therapy of phototherapy and topical tacrolimus in vitiligo treatment. J. Eur. Acad. Dermatol. Venereol., 27, 609-616.

Lotti, T., Buggiani, G., Troiano, M. (2008). Targeted and combination treatment for vitiligo. Comparative evaluation of different current modalities in 458 subjects. Dermatol. Ther., 21, 20-S26.

Majid, I. (2010). Does topical tacrolimus ointment enhance the efficacy of narrow-band ultraviolet B therapy in vitiligo? A left-right comparison study. Photodermatol. Photoimmunol. Photomed., 26, 230-234.

Mehrabi, D., Pandya, A. G. (2006). A randomized, placebo-controlled, double-blind trial comparing narrowband UV-B plus placebo in the treatment of generalized vitiligo. Arch. Dermatol., 142, 927-929.

Moretti, S., Spallanzani, A., Amato, L., Hautmann, G., Gallerani, I., Fabiani, M. (2002). New insights into the pathogenesis of vitiligo: Imbalance of epidermal cytokines at sites of lesions. Pigment Cell Res., 15, 87-92.

Njoo, M., Bos, M. S., Westerhof, W. (2000). Treatment of generalized vitiligo in children with narrow-band (TL-01) UVB radiation therapy. $J$. Amer. Acad. Dermatol., 42, 245-253.

Nordal, E. J., Guleng, G. E., Rönnevig, J. R. (2011). Treatment of vitiligo with narrowband-UVB (TL 01) combined with tacrolimus ointment $(0.1 \%)$ vs. placebo ointment, a randomized right/left double-blind comparative study. J. Eur. Acad. Dermatol. Venereol., 25, 1440-1443.

Ongenae, K., Beelaert, L., van Geel, N., Naeyaert, J. M. (2006). Psychosocial effects of vitiligo. J. Eur. Acad. Dermatol. Venereol., 20, 1-8.

Ponsonby, A. L., Lucas, R. M., van der Mei, I. A. (2005). UVR, vitamin D and three autoimmune diseases - multiple sclerosis, type I diabetes, rheumatoid arthritis. Photochem. Photobiol., 81, 1267-1275.

Satyanarayan, H. S., Kanwar, J. A., Parsad, D., Vinay, K. (2013). Efficacy and tolerability of combined treatment with NB-UVB and topical tacrolimus versus NB-UVB alone in patients with vitiligo vulgaris: A ran- domized intra-individual open comparative trial. Indian J. Dermatol. Venereol. Leprol., 79, 525-527.

Seirafi, H., Farnaghi, F., Firooz, A., Vasheghani-Farahani, A., Allirezale, N. S., Dowlati, Y. (2007). Pimecrolimus cream in repigmentation of vitiligo. Dermatology, 214, 253-259.

Senft, D., Ronai, Z. A. (2016). Immunogenic, cellular, and angiogenic drivers of tumour dormancy: A melanoma view. Pigment Cell Melanoma Res., 1, 27-42.

Sisti, A., Sisti, G., Oranges, C. M (2016). Effectiveness and safety of topical tacrolimus for repigmentation in vitiligo: A comprehensive literature review. An. Bras. Dermatol., 91, 187-195.

Taieb, A., Alomar, A., Böhm, M., Dell'anna, M. L., De Pase, A., Eleftheriadou, V., Ezzedine, K., Gauthier, Y., Gawkrodger, D. J., Jouary, T. (2013). Guidelines for the management of vitiligo: The European Dermatology Forum consensus. Brit. J. Dermatol., 168, 5-19.

Taieb, A., Picardo, M. (2010). Epidemiology, definitions and classification. In: Vitiligo. Springer, Berlin-Heidelberg, pp. 13-24.

Taieb, A., Picardo, M., VETF Members (2007). The definition and assessment of vitiligo: A consensus report of the Vitiligo European Task Force. Pigment Cell Res., 20, 27-35.

Taieb, A., Picardo, M. (2009). Clinical practice: Vitiligo. New Eng. J. Med., 360, 160-169.

Tran, C., Lubbe, J., Sorg, O. (2005). Topical calcineurin inhibitors decrease the production of UVB-induced thymine dimers from hair less mouse epidermis. Dermatology, 211, 341-347.

Westerhof, W., d'Ischia, M. (2007). Vitiligo puzzle: The pieces fall in place. Pigment Cell Res., 20, 345-359.

Whitton, M. E., Pinart, M., Batchelor, J., Lushe, C., Leonardi-Bee, J., González, U. (2010). Interventions for vitiligo. Cochrane Database Syst. Rev., 20 (1), CD003263.

Wu, C. S., Yu, C. L., Lan, C. C. E., Yu, H. S. (2004). Narrow-band ultraviolet $\mathrm{B}$ stimulates proliferation and migration of cultured melanocytes. Exp. Dermatol., 13, 755-763.

Received 15 July 2020

Accepted in the final form 24 January 2021

\section{ŠAURA SPEKTRA UVB FOTOTERAPIJA UN LOKĀLO KALCINEIRĪNA INHIBITORU LIETOŠANA VITILIGO ĀRSTĒŠANAI BËRNIEM REĀLĀ KLİNISKĀ PRAKSĒ}

Vitiligo ir dzīves laikā iegūta hroniska ādas slimība, kurai raksturīga progresējošu, bieži simetrisku, depigmentēu laukumu attīstība ādā. Vitiligo skar $0,5 \%$ populācijas, tomēr nav skaidrs, kāda ārstēšanas metožu kombinācija būtu optimālākais variants. Pētījuma mērḳis bija novērtēt, vai kombinēta ārstēšana ar UVB fototerapiju un kalcineirīna inhibitoriem nodrošina efektīvāku rezultātu pacientiem ar vitiligo, salīdzinājumā ar to, ja šīs metodes būtu lietotas katra atseviški. No 2016. gada janvāra līdz 2019. gada decembrim mēs veicām retrospektīvu kohorta pētījumu bērniem, kuri ārstēti ar vitiligo. Kā primārais rezultātu izvērtējuma rādītājs tika ietverta klīniskā efektivitāte, kas tika noteikta pēc sasniegtās repigmentācijas apgabala — laba klīniskā efektivitāte (repigmentācija $\geq 50 \%$ no bojājuma virsmas laukuma), pozitīva, bet vāja klīniskā efektivitāte (atkārtota pigmentācija < 15\% no bojājuma virsmas laukuma). Sekundārie rezultātu izvērtējuma parametri ietvēra bojājuma laukuma mazināšanos un terapijas panesamību. Kopuma pētījumā tika iekḷauti 114 pacienti. 46 pacientiem tika nozīmēta tikai lokālā ārstēšana ar kalcineirīna inhibitoriem, 36 - tikai šaura spektra UVB fototerapija un 32 — kombinēta terapija. Visas ārstēšanas metodes statistiski nozīmīgi samazināja bojājuma virsmas laukumu, salīdzinot ar sākotnējo. Lokālā terapija samazināja bojājuma laukumu no 8,5 (5,7) līdz 5,3 (4,2) kopumā par 37,3\% ( $p<0,0001)$, Fototerapija reducēja bojājumus no 9,8 $(5,4)$ līdz 5,7 (3,92) kopumā par $42,3 \%(p<0,0001)$, un kombinētā terapija samazināja bojājumus no14,2 $(4,8)$ līdz 6,58 $(3,5)$ kopumā par 53,6\% $(p<0,0001)$. Kombinētā terapija uzrādīja augstāku skaitlisko efektivitāti. Kalcineirīna inhibitoru monoterapijas klīniskā efektivitāte bija 67,4\%, fototerapijas — $80,5 \%$ un kombinētā terapijas - 93,7\%. Terapijas drošuma profils bija analoğisks citiem pētījumiem. Mūsu pētījuma rezultāti apstiprina kombinētās terapijas efektīvu pielietošanu pacientiem ar vitiligo. 